\title{
PELAKSANAAN MODEL COOPERATIVE LEARNING TIPE MAKE A MATCH DALAM MENINGKATKAN MINAT BELAJAR IPA DI KELAS V SD NEGERI 2 RIDGE I BIAK PAPUA TAHUN AJARAN 2016/2017
}

\author{
Rosdianah, Patma Tuasikal \\ Sekolah Tinggi Keguruan dan Ilmu Pendidikan (STKIP) Biak- Papua \\ E-mail: fatma.tuasikal90@gmail.com, \\ E-mail: rosd67436@gmail.com
}

\begin{abstract}
Abstrak
Berdasarkan hasil pengamatan di SD Negeri 2 Biak pelaksanaan model pembelajaran Tipe Make A Match mampu meningkatkan minat belajar siswa pada mata pelajaran Ilmu Pengetahuan Alam (IPA), namun kenyataan dilapangan menunjukan bahwa peserta didik cenderung diam jika diberi pertanyaan. Karena model pembelajaran yang dilaksanakan selama ini kurang variatif, hanya bersifat konvensional pada setiap pembelajaran, serta kurang penguasaan guru terhadap model-model pembelajaran yang inovatif, sehingga model yang digunakan guru mata pelajaran IPA berorientasi pada model ekspositori, yaitu hanya mendengar, mencatat dan mengerjakan latihan. Penelitian ini bertujuan untuk mengetahui Pelaksanaan Model pembelajaran Cooperatif Tipe Make A Match dalam meningkatkan minat belajar siswa kelas V SD Negeri 2 Biak tahun pelajaran 2016/2017 di Kecamatan Samofa, Kabupaten Biak_Numfor .Jenis penelitian ini adalah Deskriptif Kualitatif. Populasi dan Sampel penelitian ini adalah guru mata pelajaran IPA dengan teknik random sampling yang berjumlah 3 guru Mata Pelajaran IPA dan 27 Responden siswa Kelas V SD Negeri 2 di tambah 1 orang wali kelas. Data penelitian dikumpulkan melalui metode teknik observasi, angket, wawancara dan dokumentasi. Data yang terkumpul dianalisis dengan deskriptif kualitatif dengan yaitu. Display data, analisa data dan penarikan kesimpulan. Hasil penelitian menunjukkan bahwa dalam pelaksanaan model Cooperative Learning Tipe Make A Match minat belajar siswa cukup baik yang dilihat berdasarkan Jawaban Responden 27 Siswa yang menunjukan bahwa Pelaksanakan Model Cooperative Learning Tipe Make A Match meningkatkan minat belajara siswa pada Mata pelajaran IPA, yang dilihat berdasarkan kerjasama antara kelompok dan terciptanya kemandirian. Adapun faktor pendorong dan penghambat dalam pelaksanaan model Cooperative Learning Tipe Make A Match bersifat faktor ekternal dan internal, ekternal berkaitan dengan Kompetensi guru, penggunaan model yang tepat sesuai materi pembelajaran sedangkan internal berkaitan dengan kematangan siswa yaitu mentalnya, selalu melakukan latihan serta motivasi dari dalam diri serta lingkungan dan keluarga.
\end{abstract}

Keywords: Pelaksanaan Model CTL TMM, Minat Belajar 


\section{PENDAHULUAN}

Pendidikan sebagai salah satu wadah yang penting bagi pembentukan watak generasi penerus bangsa, secara strategis mampu meningkatkan kualitas manusia mencerdaskan kehidupan bangsa dalam mewujudkan cita-cita demi kesejahteraan umum. UndangUndang No 20 Tahun 2003 tentang sistem pendidikan nasional cukup tegas dijelaskan dalam mengembangkan dan membentuk watak peradaban bangsa yang bermartabat dalam rangka mencerdaskan kehidupan bangsa tujuan utamanya mengembangkan potensi peserta didik agar menjadi manusia yang beriman dan bertakwa kepada Tuhan Yang Maha Esa berakal mulia, sehat, berilmu, cakap, kreatif, mandiri sehingga mampu menjadi warga negara yang kritis dan demokratis serta peka terhadap perkembangan zaman.

\begin{tabular}{cccc} 
Proses & \multicolumn{2}{c}{ pendidikan } & mampu \\
membantu & peserta & didik & untuk \\
berkembang & secara optimal & sesuai
\end{tabular} potensi yang di miliki serta sistem nilai yang dianut dalam masyarakat, sebab pendidikan bukanlah proses memaksakan kehendak guru pada muridnya, melainkan mampu menciptakan lingkungan yang kondusif bagi perkembangan anak secara aktif dan guru sebagai sarana atau model bagi peserta didik. Pendidikan dasar enam tahun bukan hanya memberi bekal kemampuan intelektual dasar dalam membaca, menulis serta berhitung, melainkan sebagai suatu proses dalam mengembangkan kemampuan dasar peserta didik secara optimal baik aspek sosial maupun personal. Karena apabila kemampuan setiap siswa dapat dikembangkan setelah penerapan model Tipe Make A Match, maka dengan sendirinya minat belajar setiap siswa dapat meningkat. Hal demikain sejalan dengan pandangan dari Huda (2012:135) bahwa Tipe Make
A Match merupakan teknik mencari pasangan sambil mempelajari konsep atau topik tertentu dalam suasana yang menyenangkan. Karena model pembelajaran dengan tujuan mengajak siswa mencari jawaban terhadap suatu pertanyaan atau pasangan dari suatu konsep melalui suatu permainan kartu pasangan. Kartu-kartu tersebut terdiri dari kartu yang berisi pertanyaanpertanyaan dan kartu yang berisi jawaban dari pertanyaan-pertanyaan tersebut (Agus Suprijono, 2016:113).

Suasana yang menyenangkan mampu meningkatkan minat belajar siswa yang akan berdampak pada keberhasilan individu, hal demikian dipertegas dengan pandangan Slameto ( 2013: 57) bahwa minat cenderung memperhatikan dan mengenang beberapa kegiatan yang diminati seseorang, dengan terus menerus dan rasa senang. Di sisi lain Syah (2012:201) menegaskan minat adalah kecenderungan dan gairah yang tinggi atau keinginan yang besar terhadap sesuatu, karena apabila seorang telah memiliki keinginan yang besar maka apapun bisa yang lakukan untuk mengapainya. Oleh sebab itu, peserta didik mampu meningkatkan minat belajar secara baik dan sebaliknya siswa yang mempunyai minat belajar menurun maka mempengaruhi hasil belajar. Sehingga minat belajar yang dimiliki siswa besar pengaruhnya terhadap keberhasilan belajar siswa.

Hasil observasi 5 Februari 2017 pada SD Negeri 02 Biak, selama pelaksanaan kegiatan pembelajaran IPA berlangsung, masih banyak peserta didik cenderung diam jika diberi pertanyaan. Karena model pembelajaran yang dilaksanakan selama ini kurang variatif, dan bersifat konvensional pada setiap pembelajaran, serta kurang penguasaan guru terhadap model-model pembelajaran yang 
inovatif, sehingga model yang digunakan guru mata pelajaran IPA berorientasi pada model ekspositori, yaitu hanya mendengar, mencatat dan mengerjakan latihan.

Permasalahan yang terjadi mengakibatkan minat belajar peserta didik menurun, sehingga perlu adanya pembaharuan dalam proses pembelajaran baik penggunaan model pembelajaran yang sesuai dengan kondusif peserta didik, maupun karakteristik setiap peserta didik, sehingga guru mampu menumbuh kembangkan ketertarikan siswa terhadap mata pelajaran IPA. Setiap guru diharapkan untuk berusaha menemukan model pembelajaran yang tepat untuk pelaksanaan pembelajaran IPA di kelas,agar pembelajaran berjalan lancar dan dapat meningkatkan minat serta prestasi belajar siswa. Oleh sebab salah satu model pembelajaran yang mampu meningkatkan minat belajaran siswa dalam pelaksanaan pembelajaran yaitu model pembelajaran Tipe Match A Match. Hal demikian dipertegas oleh pandangan Rusman (2011: 223-233) bahwa Model Tipe Make A Match atau (membuat pasangan) merupakan salah satu jenis dari metode pembelajaran kooperatif yang bisa diterapkan pada mata pelajaran IPA.

Penelitian ini dilakukan berdasarkan penelitan terdahulu yang dilakukan oleh Ayu Nur Aisyah (2017) bahwa Penerapan Model Pembelajaran Kooperatif Tipe Make A Match dapat meningkatkan Prestasi Belajar, yang dilihat berdasarkan peningkatan ketuntasn belajar dan ketercapain indikator. Hal demikian menunjukan bahwa peningkatan minat belajar tergantung pada pengelolaan dan penggunaan model sesuai dengan materi pelajaran. Selain itu ditegaskan juga oleh hasil penelitian Ayu Febriana (2011) menunjukan bahwa dengan menerapkan model pembelajaran kooperatif model Tipe Make A Match dapat meningkatkan kualitas pembelajaran pembelajaran sosial kelas lima SDN Kalibanteng Kidul 01 Semarang. Saran yang bisa diberikan adalah model tipe koperasi Make A Match yang perlu diaplikasikan dan dikembangkan karena dapat meningkatkan kemampuan guru, aktivitas siswa dan prestasi belajar sehingga dapat mempengaruhi peningkatan pembelajaran sosial.

Selain itu, peneitian terdahulu oleh Nurlia Astika \& Ngurah Ayu Nyoman M, (2010) yang menunjukan bahwa al penelitian ini dapat disimpulkan bahwa model pembelajaran kooperatif tipe make a-match lebih efektif meningkatkan hasil belajar siswa bila dibandingkan dengan model pembelajaran konvensional. sebab menurut Abdul Majid,( 2013:13) yang dikutip dari Arends (1997) bahwa model pembelajaran mengarah pada suatu pendekatan pembelajaran tertentu termasuk tujuannya, sintaksnya, lingkungan, dan sistem pengelolaannya.

\section{METODE PENELITIAN}

Penelitian pelaksanaan model Cooperative Learning Tipe Make a Match peneliti bermaksud untuk meningkatkan minat belajar siswa secara mendalam dan komprensif. Selain itu, pendekatan kualitatif diharapkan dapat diungkapkan faktor dan kendala apa yang menyebabkan menurunnya minat belajar siswa pada pelajaran IPA. Penelitian tentang Pelaksanaan Model Cooperative Learning Tipe Make a Match dalam meningkatkan minat belajar pada Sekolah Dasar Negeri 2 Ridge I Biak. Subjek dalam penelitian yaitu seluruh guru Sekolah Dasar 2 Ridge I Biak yang yang berjumlah 10 orang untuk melihat pelaksanaan Model Cooperative learning tipe make a match dalam meningkatkan 
minat belajar IPA pada Sekolah Dasar Negeri 2 Ridge I Biak.

Penelitian ini menggunakan teknik Probability sampling meliputi random sampling pada guru mata pelajaran IPA, yang di ambil dari sebagian populasi yang benar-benar memahami Pelaksanaan Model Cooperative Learning Tipe Make a Match pada Sekolah Dasar Negeri 2 Ridge I Biak, Yang terdiri dari 3 orang guru mata pelajaran IPA, yang melaksanakan Model Cooperative Learning Tipe make a match.

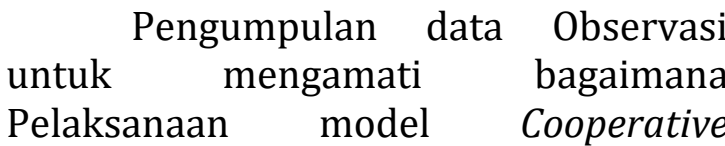
Learning Tipe Make A Match dalam meningkatkan minat belajar IPA siswa kelas V SD Negeri 2 Ridge I Biak, wawancara secara mendalam dengan guru mata pelajaran IPA, sehingga pertanyaan wawancara yang diajukan akan berkembang dengan sendirinya, terutama pada guru yang mengajar kelas V SD untuk mengetahui tentang (1) Pelaksanaan model yang diterapkan, selama proses pembelajaran, (2) Faktor pendorong dan penghambat pelaksanaan model Cooperative Learning Tipe Make A Match dalam meningkatkan minta beajar. Dokumentasi dilakukan untuk membantu peneliti, dalam mengungkapkan penggunaan metode dalam pembelajaran oleh guru mata pelajaran IPA, serta sebagai salah satu bukti bahwa peneliti benar-benar melakukan penelitian. Sedangkan angket digunakan untuk mengetahui Pelaksanaan Model Cooperative Learning Tipe Make A Match pada jumlah siswa sebanyak 30 orang, sehingga lebih membudahkan peneliti dalam pengambilan data.

Penelitian ini dianalisis dengan metode deskritif kualitatif. Teknik analisis data yaitu Pengumpulan Data (Data Collection), Reduksi Data (Data
Reduction), Display Data, Verifikasi dan Penarikan kesimpulan (Conclution Drawing and Verification) berupa kegiatan interpretasi, yaitu menemukan makna data yang telah disajikan. Antara display data dan penarikan kesimpulan terdapat aktivitas analisis data yang ada. (Sugiyono, 2016:247).

\section{HASIL DAN PEMBAHASAN}

SD Inpres Ridge 2 Biak berdiri pertama kali Pada Tahun 1963 dengan menempati kompleks Sanggar Kegiatan Belajar atau disingkat SKB. Kemudian pada tahun 1968 dipindahkan ke Ridge 1 dengan nama sekolah "Sekolah Dasar Negeri 2 Ridge 1 Biak ". Sesuai kesepakatan pemilik hak ulayat dengan menyerahkan tanah $40 \times 60 \mathrm{~m}^{2}$ dengan luas tanah sekolah $2736 \mathrm{~m}^{2}$ dan luas bangunan $651 \mathrm{~m}^{2}$. SD Negeri 2 Ridge 1 Biak mulai beroperasi pada tahun 1965 . Selanjutnya sekolah ini beroperasi sampai terakreditasi C pada tahun 1993. Perkembangan selanjutnya mengimbaskan SD Inpres Ridge 2. Dan pada tahun 2016 sudah terakreditasi kembali dengan akreditasi nilai B. Selain itu selama proses beropreasinya sekolah tersebut, ada beberapa nama kepala sekolah yang pernah memimpin. Adapun nama-nama Bapak/Ibu kepala sekolahnya yaitu Matulesi, B. Sitorus, Purwanto, L. Papasoka dan Juriati Butar-Butar sampai sekarang. Selain itu tujuan pendidikan dasar sesuai dengan peraturan pemerintah No.19 tahun 2015 adalah meletakan dasar kecerdasan, pengetahuan, kepribadian, akhlak mulia, serta keterampilan untuk hidup mandiri dan untuk mengikuti pendidikan lebih lanjut.

Mendasari pernyataan di atas, maka Visi Sekolah Dasar Negeri 2 Biak adalah beriman dan taqwa kepada Tuhan, mandiri, unggul, dan berprestasi, sedangkan Misi Sekolah terdiri atas lima point; Pertama Meningkatkan iman dan taqwa, serta akhlak mulia sesuai ajaran 
agama, Kedua Memberdayakan dan meningkatkan profesi guru, Ketiga Meningkatkan kecerdasan, minat, dan potensi peserta didik, ke empat Memberikan bekal kemampuan dasar kejenjang pendidikan dan Kelima Membangun citra sekolah mitra masyarakat. Menindaklanjuti penjelasan di atas, maka Tujuan Sekolah Mengacu pada Visi dan Misi yang ingin dicapai sebagai berikut: Pertama Dapat menjalankan ajaran agama hasil proses pembelajaran dan pembiasaan, kedua Memiliki dasar-dasar pengetahuan, skill, dan berwawasan global ketiga Meraih prestasi akademik maupun non akademik minimal tingkat kabupaten atau kota, keempat Unggul dalam berprestasi dibidang IMTAQ dan IMTEK dan kelima Mencintai bangsa, masyarakat, dan kebudayaan.

Berdasarkan hasil penelitian yang penulis lakukan pada Tanggal 12 April 2017 , bahwa Pelaksanaan Model Cooperatif Learning Tipe Make A Match dilakukan, membawah dampak yang positif, karena model ini baru dilaksanakan pada SD Inpres Ridge 2, sehingga menjadi hal baru bagi peserta didik, mulai dari proses pembelajaran sampai pada evaluasinya, sebab sebelum pelakasanaan Model Cooperatif Learning Tipe Make A Match pada mata pelajaran IPA nilai rata-rata yang diperoleh 65 dari 20 siswa, namun setelah pelaksanaan model pembelajaran ini, nilai siswa mengalami peningkatan, hal demikian dilihat berdasarkan hasil ulangan siswa.

Mendasari penjelasan di atas, diperkuat dengan hasil angket dari 30 siswa yang menyatakan dalam pelaksanaan model tersebut membawah dampak yang cukup baik, karena rata-rata siswa mendapat nilai cukup baik setelah pelaksanaan model pembelajaran. Hal tersebut diperkuat hasil wawancara dengan guru mata pelajaran IPA SD Inpres Ridge, bahwa hasil mid semester lebih baik dibandingkan dengan hasil nilai tes kemarin, karena sebelumnya dari 20 siswa yang mendapat nilai 70 hanya 7 orang, sedangkan yang sisa mendapat nilai 40 sampai 55 (16 April 2017). Hal demikian menunjukan bahwa Pelaksanaan Model Cooperative Learning Tipe Make A Match membantu siswa memahami materi yang disampaikan, karena terlihat ketika pelaksanaan model ini peserta didik diberikan kartu-kartu yang berisi pertanyaan dan jawaban terlihat mereka sangat antusias dalam mencari pasangan yang memegang kartu pertanyaan dan jawaban.

Setelah pelaksanaan model pembelajaran itu dilaksanakaa sesuai dengan langkah- langkah akan berdampak terhadap meningkatnya minat belajar peserta didik, hal demikian diperkuat dengan hasil wawancara dengan Ibu Agustina" bahwa pelaksanaan model pembelajaran Cooperative Learning Tipe Make a Match pada kelas $\mathrm{V}$ melalui langkah-langkah yaitu guru menyampaikan materi, siswa dibagi dalam dua kelompok, guru membagikan kartu pertanyaan dan kartu jawaban, guru menyampaikan mereka harus mencari pasangan yang tepat dan guru meminta semua anggota untuk mencari pasangan sesuai waktu yang ditentukan,guru memanggil pasangan untuk presentasi dan guru memberikan konfirmasi tentang kebenaran dan kecocokan pertanyaan. (16 April, 2017).

Berdasarkan hasil penelitian dengan Guru Mata Pelajaran IPA bahwa" faktor penghambat dalam pelaksanaan Model Cooperatif Learning Tipe Make A Match yaitu" banyak waktu yang terbuang, siswa laki-laki dan perempuan terkadang malu berpasangan, banyak siswa kurang memperhatikan jika presentasi 
temannya apalagi ketika waktu presentasi mereka telah selesai, kebosanan akan muncul ketika menggunakan model pembelajaran ini terus menerus. ( 27 April 2017).

Selain itu, faktor penghambat lainya adalah Faktor ekternal dan faktor internal. Faktor ekternal berkaitan dengan luar sekolah yaitu faktor keluarga, dimana sebagian besar orang tua tidak terlalu memperdulikan anaknya ketika tidak berangkat sekolah, ini mengakibatkan mengakibatkan anak tersebut selalu jarang mengerjakan tugas sekolah, sehingga selalu menyontek punya teman di kelasnya, selain itu faktor lingkungan tempat tinggalnya, sebagian besar anak yang berada pada usia dewasa, idak baik, yang mengakibatkan dia sering bersikap kurang sopan, hal ini didapat dari hasil wawancara dengan guru kelasnya ibu kristian" lingkungan tempat tinggalnya banyak orang dewasa, anak kecil hanya beberapah orang" sehingga berakibat pada sikap dan tingkah lakunya.

Faktor internal berkaitan dengan Minat belajar siswa, Sikap guru dan fasilitas sekolah, karen hal ini sangat penting dalam meningkatkan minat belajar peserta didik. Hal ini dipertegas dengan hasil Wawancara dari guru kelas V bahwa" jika semua guru mata pelajaran berperilaku baik, akan menjadi contoh yang baik buat peserta didik, dan fasilitas sekolah akan menunjang dalam proses pembelajaran, seperti infokus ruang kelas yang bersih, ada tempat sampah dan lainya (10 Mei 2017)

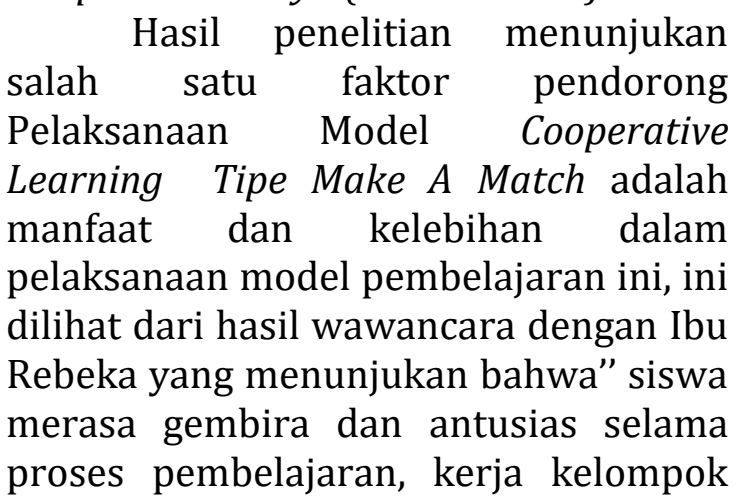

antara kelompok berjalan baik, muncul sifat gotong royong yang rata di kelas, dan murid laki-laki dan perempuan menjadi pasangan sambi belajar sehingga suasana belajar lebih menyenangkan. (Wawancara, 16 Mei 2017).

Selain itu, faktor pendorong lain yang di alami siswa selama Pelaksanaan Model Cooperative Learning Tipe Make A Match adalah peserta didik bersikap mandiri dengan cara mencari jawaban untuk mencocokan dengan kartu soal yang di milikinya dan siswa merasa senang dan menyukai pelajaran IPA, sehingga pelaksanaan model pembelajaran Cooperative Learning Tipe Make A Match menjadi pendorong karena mampu meningkatkan minat belajar peserta didik. Hal ini dipertegas oleh salah seorang siswa kelas V bahwa" saya suka pelajaran IPA karena kita belajar sambil bermain untk mencari jawaban yang cocok dengan soal saya. (Wawancara, 16 Mei 2017).

Pernyataan di atas dipertegas oleh hasil Wawancara dengan peserta didik laki-laki kelas $\mathrm{V}$ bernama john yang mengatakan bahwa" kalau ada jam IPA saya mau kesekolah dan belajar karena saya suka belajar dengan lari untuk mencari teman dan mendapat jawaban. (Wawancara, 20 Mei 2017).

Dari hasil wawancara antara peserta didik dengan guru mata pelajaran IPA yang melaksanakan Model Cooperative Learning Tipe Make A Match menunjukan bahwa faktor pendorong utama sesuai dengan indikator pelaksanaan model ini yaitu indikator minat atau perasaan suka yang dialami oleh peserta didik terhadap suatu hal/kegiatan hal ini terlihat menimbulkan kesenangan serta kepuasaan melalui pertanyaan atau aktivitas peserta didik.

Berdasarkan hasil penelitian dalam Pelaksanaan Model Cooperative Learning Tipe Make A Match 
menunjukan suatu pelaksanaan model pembelajaran akan berhasil apabila harus di sesuaikan dengan keadaan siswa, sehingga guru dituntut untuk lebih variatif dalam penggunaan model pembelajaran karena mata pelajaran IPA menuntut peserta didik untuk mampu bukan hanya dalam berhitung, namun mampu memecahkan persoalan dalam kehidupan sehari-hari. Dengan adanya pelaksanaan model pembelajaran ini siswa di tuntut aktif dan mampu bekerjasama dengan siswa lainnya dalam menyelasikan masalah. Pandangan tersebut ditegaskan oleh Hosnan (2014:235) bahwa pembelajaran cooperatif adalah strategi pembelajaran yang sukses dimana tim dan masing-masing siswa dari tingkat kemampuan yang berbeda menggunakan berbagai aktivitas belajar untuk meningkatkan pemahaman mereka tentang suatu objek. Selain itu, Wina Sanjaya (2016:242). Menegaskan pembelajaran kooperatif menggunakan sistem pengelompokan atau tim kecil, yaitu antara empat sampai enam orang yang mempunyai latar belakang kemampuan akademik, jenis kelamin, ras, atau suku yang berbeda. Sedangkan Sugiyanto (2010:37) model pembelajaran kooperatif adalah pendekatan yang berfokus pada penggunaan kelompok kecil siswa untuk bekerja sama dalam memaksimalkan kondisi belajar untuk mencapai tujuan belajar.

Selain itu, dalam Pelaksanaan Model Cooperative Learning Tipe Make A Match indikator minat belajar siswa sangat berpengaruh terhadap pelaksanaan pembelajaran sebab, semakin meningkat minat belajar peserta didik akan berdampak pada pengetahuan siswa baik kognitif, afektif dan psikomotorik, sehingga selama Pelaksanaan Model Cooperative Learning Tipe Make A Match pada SD Negeri 2 Ridge Biak membawah dampak positif yaitu minat belajar peserta didik meningkat. Hal ini ditegas oleh pandangan Winkel (1983:30) bahwa minat adalah kecendurungan yang menetap dalam subjek untuk merasa senang berkecimpung dalam bidang itu. Menindaklanjuti konsep di atas, dalam Pelaksanaan Model Cooperative Learning Tipe Make A Match terdapat faktor penghambat dan pendorong baik faktor ekternal dan faktor internal. Faktor internal biasa datang dari dalam diri siswa salah satu satunya motivasi belajar sesui dengan hasil penelitian, sebab motivasi merupakan pendorong bagi siswa untuk melakukan sesuatu sehingga ia berusaha mempelajari sesuatu dengan sebaik-baiknya, seperti mata pelajaran IPA. Karena peserta didik merasa sengang dengan model yang diterapkan akan berpengaruh terhadap minat belajar siswa yang meningkat.

Faktor internal lainnya yaitu kematangan siswa, hal sesuai dengan hasil penelitian yang menunjukan bahwa siswa beranggapan Pelaksanaan Model Cooperative Learning Tipe Make A Match sebagai suatu permainan, padahal model ini malatih peserta didik untuk lebih mandiri dalam memecahkan suatu permasalahan. Pandangan peserta didik tersebut bergantung pada kematangan dalam diri siswa yang dipengaruhi oleh mentalnya. Karena mengajarkan sesuatu pada siswa dapat dikatakan berhasil jika taraf pertumbuhan pribadi telah memungkinkan dan potensi jasmani serta rohaninya telah matang untuk menerimah hal yang baru. Selain itu faktor penting yaitu latihan dan ulangan. Hal ini berdasarkan hasil penelitian yaitu pelaksanaan model Cooperative Learning Tipe Make A Match melatih peserta didik dalam memecahkan masalah, sehingga mereka terlatih dan sering mengulangi sesuatu, maka kecakapan dan pengetahuan yang 
dimiliki peserta didik dapat menjadi dikuasai. Karena apabila peserta didik tidak latihan maka pengalamanpengalaman yang dimiliki akan hilang. Mendasari penjelasn di atas, jika dilihat berdasarkan faktor ekternal berkaitan dengan faktor dari luar, ini berkaitan dengan hasil penelitian yang menunjukan bahwa guru adalah salah satu faktor penting, sebab guru dituntut untuk mampu menumbuh kembangkan minat dari siswa. Segala penampilan guru yang tersurat dalam kompotensi guru sangat berpengaruh terhadap sikap dan peserta didik. Sebab kompotensi guru yang bersifat personal berhubungan dengan kepribadian guru dan kompotensi profesional berkaitan dengan kemampuan penguasaan seluk beluk materi yang dapat menyangkut materi pelajaran.

Faktor lain adalah Metode pembelajaran. Hal ini sesuai dengan hasil penelitian yang menunjukan bahwa model Cooperative Learning Tipe Make A Match mampu meningkatkan minat belajar siswa yang digunakan oleh guru, sebab menarik tidak suatu materi pelajaran tergantung pada keahlian guru dalam menggunakan metode atau model yang tepat. Sedangkan hasil penelitian menujukan faktor lain adalah materi pelajaran, sehingga peneliti menggunakan mata pelajaran IPA sebab dalam mata pelajaran IPA ada materi mengenal tumbuhan dan manfaatnya sesuai dengan model yang di gunakan, sehingga mampu dalam pelaksanaan model Cooperative Learning Tipe Make A Match mampu meningkatkan minat belajar Siswa Kelas V SD Negeri 2 Ridge Biak.

\section{PENUTUP}

Dalam Pelaksanaan Model Cooperatif Leraning Tipe Make a Match cukup baik karena antusias peserta didik dalam penggunaan model ini sangat positif, ini terlihat dengan adanya kerjasama yang baik antara kelompok satu dengan kelompok yang lain, terutama dalam mencari jawaban yang sesuai dengan soal yang terdapat pada kartu yang dimilikinya.

Faktor Penghambat dalam Pelaksanaan Model Cooperatif Leraning Tipe Make a Match dilihat berdasarkan, pelaksanaan model ini memakan waktu yang cukup lama, sehingga membutukan waktu yang panjang, padahal setiap mata pelajaran hanya memakan waktu 1 sampai 2 jam, selain itu, penggunaan model ini tidak bisa dilaksanakan berulang-ulang karen akan menimbulkan kebosanan pada peserta didik. Faktor lainnya yaitu, keluarga, lingkungan dan pengaruh Teknologi dan Informasi.

Faktor Pendorong dalam

Pelaksanaan Model Cooperatif Leraning Tipe Make a Match adalah faktor Internal dan Ekternal yang berasal dari dalam diri siswa berkaitan dengan Motivasi peserta didik atau Minat belajar siswa, Latihan atau Kemandirian Peserta didik dan Mental, sedangkan Fator Eksternal berkaitan dengan Kompotensi guru personal maupun profesional. Materi Ajar dan Model Pembelajaran yang digunakan.

\section{DAFTAR PUSTAKA}

Abdul Majid.(2013). Perencanaan Pembelajaran. Bandung: PT Remaja. Rosdakarya.

Agus Suprijono. (2016). Cooperative Learning. Yogyakarta: Pustaka Belajar

Ayu Febriana. (2011). Penerapan Model pembelajaran Kooperatif Tipe Make A Match Untuk Meningkatkan Kualitas Pembelajaran IPS Siswa Kelas V SDN Kalibanteng Kidul 01 Kecamatan Semarang (Application Of Cooperatif Learning Type Make A Match To Enhance Quality of 
Learning Social. Jurnal Kependidikan Dasar, Vol 1 Nomor 2 Tahun 2011,

Huda. 2012. Cooperative Learning: Metode, Teknik, Struktur, dan Model Penerapan. Pustaka Pelajar. Yogyakarta.

Nur Aisyah Ayu. (2017). Penerapan model pembelajaran kooperatif tipe Make a match untuk meningkatkan prestasi belajar kompetensi dasar membukukan jurnal penyesuaian. Skripsi Fakultas Ekonomi Universitas Negeri Yogyakarta 12 April 2017

Nurlia Astika \& Ngurah Ayu Nyoma. (2010). Efektivitas Model Pembelajaran Kooperatif Tipe Make A-Match Terhadap Hasil Belajar Siswa, Jurnal Penelitian Pembejaran Fisika Vol. 3 No. , September 2012.

Rusman. 2011. Model-Model Pembelajaran: Mengembangkan Profesionalisme

Guru. Rajawali Pers, Jakarta.
Slameto. (2012). Belajar dan Faktorfaktor yang Mempengaruhi. Jakarta: PT Rineka Cipta.

Syah, Muhibbin.2013. Psikologi Pendidikan dengan Pendekatan Baru. Bandung: Remaja Rosdakarya

Sugiyono. (2016). Metode Penelitian Kuantitaif, Kualitatif dan R\&D. Bandung: Penerbit Alfabeta.

Sanjaya, Wina. (2010). Strategi Pembelajaran Berorientasi Standar Proses. Pendidikan. Jakarta : Prenada Media Group.

Sugiyanto.2010. Model-Model Pembelajaran Inovatif. Surakarta : Yuma Pustaka.

Winkell, WS. 1983. Psikologi Pendidikan dan Evaluasi Belajar. Jakarta: Gramedia.

Undang- Undang Nomor 20 Tahun 2003 Tentang Sistem Pendidikan Nasional 